\title{
Physicochemical, textural, volatile, and sensory profiles of traditional Sepet cheese
}

\author{
D. Ercan, ${ }^{\star}$ F. Korel, ${ }^{* 1}$ Y. Karagül Yüceer,† and Ö. Kınık‡ \\ *Department of Food Engineering, Izmir Institute of Technology, Urla, Izmir, Turkey \\ †Department of Food Engineering, Canakkale Onsekiz Mart University, Canakkale, Turkey \\ ‡Department of Dairy Technology, Ege University, Bornova, Izmir, Turkey
}

\section{ABSTRACT}

Characterization of traditional cheeses is important for the protection of diversity of tradition and contributing baseline data for further research and quality control. Sepet cheese is a traditional cheese and specific to the Aegean region of Turkey. In this study, 52 Sepet cheese samples were analyzed to characterize the physicochemical, textural, volatile compounds, and sensory profiles. The changes in the physicochemical and volatile compositions were investigated during production and ripening periods. The average dry matter (DM; 55.16\%), fat-in-DM (45.80\%), protein $(29.18 \%)$, salt-in-DM (12.88\%), water activity (0.83), $\mathrm{pH}(5.50)$, titratable acidity $(1.69 \%)$, ripening and lipolysis indices (11.06 and 6.36), firmness $(212.20 \mathrm{~N})$, springiness (0.62), cohesiveness (0.57), adhesiveness (0.48 Nmm), and chewiness $(66.87 \mathrm{~N})$ values of Sepet cheese samples were determined. Hexanoic, octanoic, decanoic, and butyric acids, which were responsible for the cheesy, waxy, goaty odors, were the most abundant volatile compounds in these cheeses. Most of the volatile compounds increased significantly during production and ripening. Significant changes in most of the physicochemical characteristics were observed up to the third month of ripening. As a result of the descriptive sensory analysis, Sepet cheeses were described with descriptors such as free fatty acid, animal like, sulfurous, creamy, cooked, and whey, and aromatics with high salty basic taste.

Key words: Sepet cheese, texture, odor, sensory profile

\section{INTRODUCTION}

Traditional cheeses are considered to be produced locally or regionally for many generations and they have an important place in rural region food culture (Weichselbaum et al., 2009). Many traditional cheese types are produced and consumed locally in Turkey

Received October 18, 2010.

Accepted May 3, 2011.

${ }^{1}$ Corresponding author: figenkorel@iyte.edu.tr
(Turkoglu et al., 2003). However, production of almost all traditional cheeses occurs to meet the local demand and those cheeses are not very well known in other regions (Tarakci and Temiz, 2009). Sepet cheese is one of the traditional cheeses of the Aegean region in Turkey. It is named Sepet (basket) cheese because the appearance of the surface of Sepet cheese has a basketweave impression. Baskets, made from stalks collected near rivers and moist areas, are used in the production of this cheese (Kamber, 2008). A photograph of Sepet cheese and a flow diagram of its production are given in Figures 1 and 2, respectively. Mostly raw goat milk is used in production (Kınık et al., 1999). Faced with extinction of some traditional cheeses and changes in milk production and cheese manufacture, a real need exists for the knowledge of characterization of texture and flavor of traditional cheeses. The acceptability of cheese by consumers is mainly based on its texture and flavor. The texture is affected during production and ripening (Beuvier and Buchin, 2004). During manufacture, milk changes physically and rheologically and the cheese matrix is formed (Gunasekaran and Ak, 2003). Then, changes in the cheese matrix continue during ripening because the matrix is influenced by the loss of water and proteolysis (Beuvier and Buchin, 2004). One of the quality parameters of cheese is its flavor. Formation of flavor compounds depends on physicochemical parameters such as moisture, salt content, $\mathrm{pH}$, and ripening conditions. Cheese flavor is derived from the breakdown of milk proteins, fats, and lactose by enzyme activities or chemical reactions (for example, via the Maillard and Strecker reactions between AA and various carbonyls; Forde and Fitzgerald, 2000; Fox et al., 2000). To date, much research has been done to demonstrate the specific characteristics of traditional cheeses (Qian and Reineccius, 2002; Hayaloglu et al., 2008; Tarakci and Temiz, 2009; Picon et al., 2010; Sánchez-Macías et al., 2010). To the best of our knowledge, no study exists that evaluates all of the aspects of traditional Sepet cheeses. Therefore, the aims of this study were to investigate the physicochemical, textural, aroma, and organoleptic characteristics of Sepet cheeses that were collected from different towns of the Aegean Region 


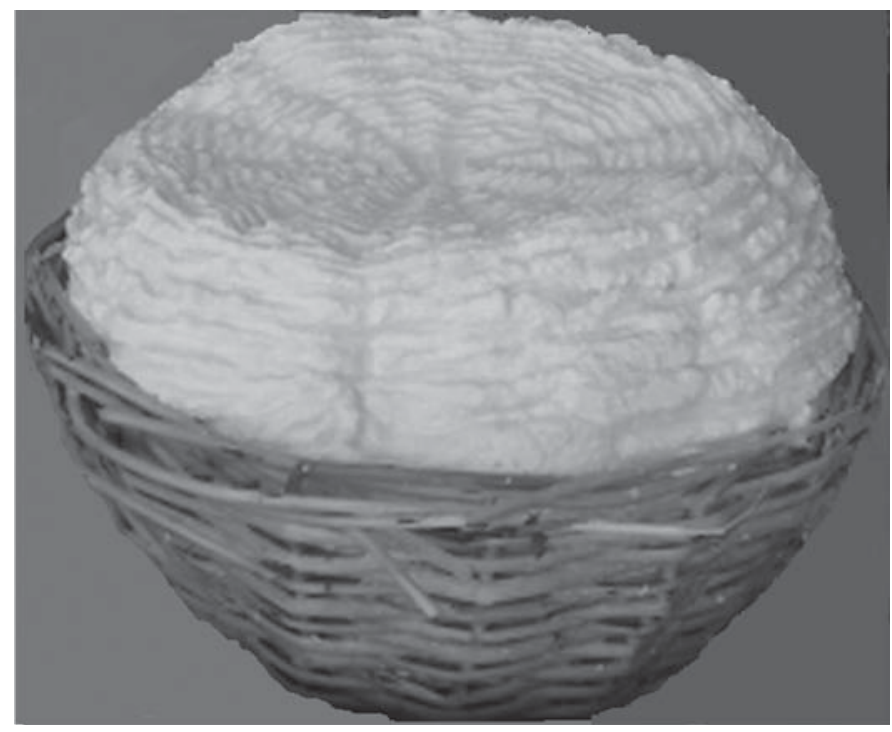

Figure 1. Photograph of Sepet cheese.

and to determine the changes of physicochemical and volatile composition of Sepet cheeses collected from 2 different farms during production and ripening for 6 mo.

\section{MATERIALS AND METHODS}

\section{Sample Collection}

Between 2008 and 2009, 52 Sepet cheese samples, which were ripened approximately for $3 \mathrm{mo}$, were collected from different towns located near Izmir, Turkey. Samples were taken to the laboratory in an ice box on the same day and they were stored at $4^{\circ} \mathrm{C}$ until analysis. Samples were also vacuum packaged and stored at $-20^{\circ} \mathrm{C}$ for volatile compound analysis.

In the second part of the study, 2 production runs were done using goat milk in dairy farms located in Zeytineli and Germiyan towns (Izmir). In Zeytineli, natural rennet was used as a coagulant agent, which was produced from the fourth stomach of a young goat. In Germiyan, microbial rennet (Mayasan A.S., Istanbul, Turkey) was used in the production. Two cheese samples (2 replicates) were produced in each production and ripened in brine in a cool and shady place. Milk, curd, first day, and first, third, and sixth month cheeses were analyzed.

\section{Physicochemical Analysis}

Cheeses were analyzed for DM by the oven-drying method (IDF, 1982), fat by the Gerber method (IDF, 1997), total nitrogen (TN) by the Kjeldahl method (IDF, 1993), salt by the Mohr method (IDF, 1988), and
$\mathrm{pH}$ by the method described by Shakeel-Ur-Rehman and Fox (2002). The water activity $\left(\mathbf{a}_{\mathrm{w}}\right)$ values of samples were measured using a water activity meter (HygroLab V3, Bassersdorf, Switzerland). Titratable acidity was determined using the method of AOAC (1995). Protein and fat contents of milk samples were measured using a Lactostar analyzer (Funke-Dr.N.Gerber Labortechnik GmbH, Berlin, Germany).

Procedures described by Bynum and Barbano (1985) and Metin (2006) were followed to determine $\mathrm{pH} 4.6$-soluble nitrogen ( $\mathbf{p H}$ 4.6-SN) and $12 \%$ trichloroacetic acid-soluble nitrogen (TCA-SN) fractions, which are the indications of the extent of proteolysis. The index of lipolysis (acid degree value) of samples was determined by using the method described by Renner (1986) and expressed as $\mathrm{mEq}$ of $\mathrm{KOH} / 100 \mathrm{~g}$ of fat. All analyses were performed in duplicate.

\section{Texture Analysis}

Cheese samples were cut into $25-\mathrm{mm}$ cubes and stored in a refrigerator before texture analysis. Texture profile analysis (TPA) test was performed in triplicate using a TA.XTPlus Texture Analyzer (Stable Microsystems Ltd., Godalming, UK). By using a $50-\mathrm{kg}$ force load cell, a double bite compression cycle was carried out

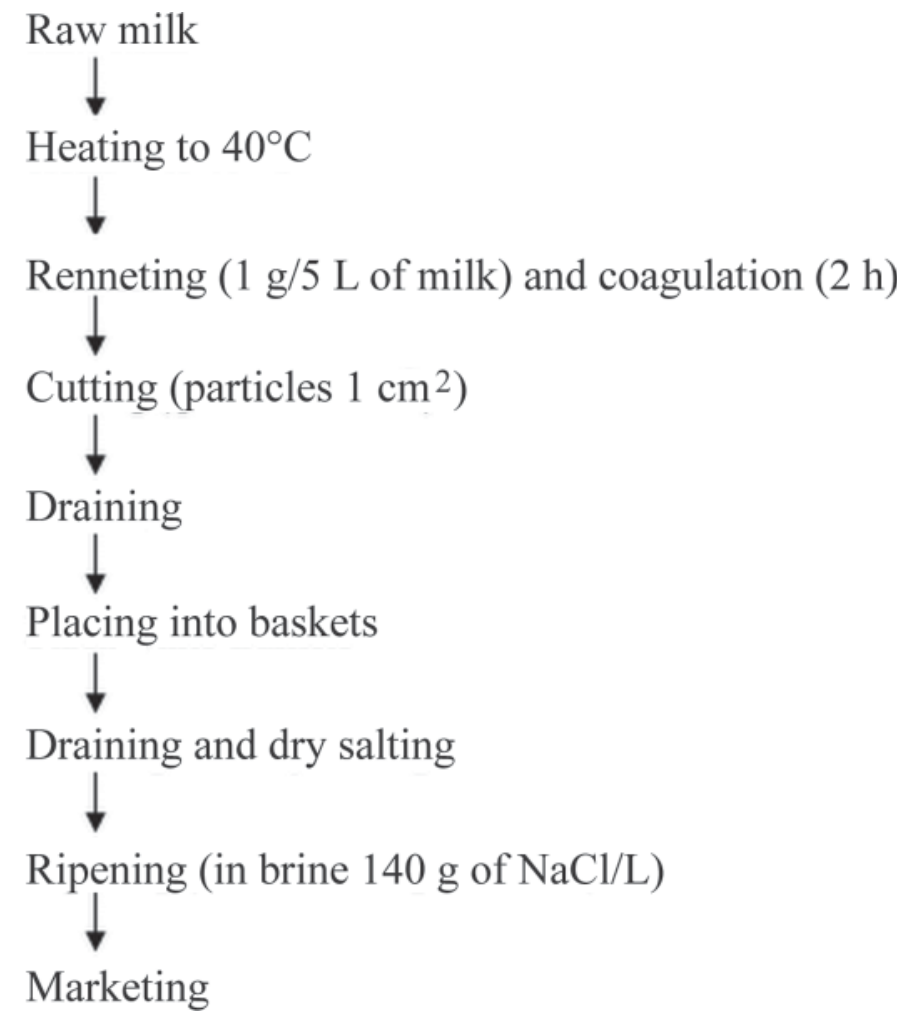

Figure 2. Flow diagram of Sepet cheese production. 
using the method described by Everard et al. (2007). Parameters of TPA were defined as given in Everard et al. (2007).

\section{Volatile Compound Analysis}

For the extraction of volatile compounds, the solidphase microextraction (SPME) method was used. For this purpose, a fiber, provided by Supelco (57348-U; Supelco Inc., Bellefonte, PA), coated with the following sorbent material: divinylbenzene/Carboxen/ polydimethylsiloxane, was used. Samples were defrosted at $4^{\circ} \mathrm{C}$ before the day of analysis. The outer surfaces of samples were removed and the samples were grated. Three grams of grated samples were weighed into a 20$\mathrm{mL}$ vial, and a PTFE/butyl septum was immediately sealed with an aluminum crimp seal. The sample was equilibrated at $60^{\circ} \mathrm{C}$ at $500 \mathrm{rpm}$ for $30 \mathrm{~min}$. Then, fiber was exposed into the headspace for $30 \mathrm{~min}$ at $60^{\circ} \mathrm{C}$ while the sample was agitated at $500 \mathrm{rpm}$. Volatile compounds adsorbed on the fiber desorbed in the injector port of the GC (Agilent Technologies, Wilmington, DE) for $5 \mathrm{~min}$.

A PerkinElmer Clarus 600 GC/olfactometry (GC/O) system (PerkinElmer Inc., Waltham, MA), equipped with a flame ionization detector, was used for the volatile compound analysis of the 52 Sepet cheese samples. The temperature of the injector port was $250^{\circ} \mathrm{C}$. The oven was temperature programmed as follows: $40^{\circ} \mathrm{C}(6$ $\min ), 5^{\circ} \mathrm{C} / \mathrm{min}$ to $100^{\circ} \mathrm{C}(2 \mathrm{~min})$, and $10^{\circ} \mathrm{C} / \mathrm{min}$ to $250^{\circ} \mathrm{C}$ (4 min). The carrier gas was He with a $1 \mathrm{~mL} / \mathrm{min}$ flow rate. A BP20 wax capillary column (SGE International Pty. Ltd., Ringwood, Victoria, Australia; $30 \mathrm{~m} \times 0.25$ $\mathrm{mm}$ i.d. $\times 0.25-\mu \mathrm{m}$ film thickness) was used. The GC/O analysis was performed by one highly trained sniffer, and aroma intensity was recorded using a 10-point scale, with 10 indicating extremely strong, 6 indicating medium intensity, 3 indicating weak intensity, and 0 indicating not detected (Qian et al., 2002). The sniffer had at least $60 \mathrm{~h}$ of experience (especially with Sepet cheese aroma) with the GC/O technique, scale using, and odor description. The analysis was performed in duplicate. Identification was done with comparison of odor and retention indices of volatile compounds and authentic standards analyzed at the same conditions. Retention indices were calculated using the $n$-alkane series (C6-C30; Van den Dool and Kratz, 1963).

For the Sepet cheeses produced in 2 different towns, the changes in volatile composition during production and ripening were investigated using GC (Agilent 6890 N Network GC Systems)-MS (5973N Network Mass Selective Detector; Agilent Technologies). An Elite-225 capillary column (PerkinElmer Instruments, Shelton, $\mathrm{CT} ; 30 \mathrm{~m} \times 0.25-\mathrm{mm}$ i.d. $\times 0.25-\mu \mathrm{m}$ film thickness) was used. The inlet temperature was $220^{\circ} \mathrm{C}$. The oven temperature was programmed as: $40^{\circ} \mathrm{C}(6 \mathrm{~min}), 5^{\circ} \mathrm{C} /$ min to $100^{\circ} \mathrm{C}(2 \mathrm{~min})$, and $10^{\circ} \mathrm{C} / \mathrm{min}$ to $220^{\circ} \mathrm{C}(5 \mathrm{~min})$. The carrier gas, He, was used at $1 \mathrm{~mL} / \mathrm{min}$. The transfer line temperature was $280^{\circ} \mathrm{C}$. The mass scan range was 26 to $350 \mathrm{amu}$ at $1.18 \mathrm{scans} / \mathrm{s}$ and ionization voltage was $70 \mathrm{eV}$. The analysis was performed in duplicate. Identification was done by comparing ion spectra and retention times with authentic standards and spectra from the mass spectral library [National Institute of Standards and Technology (NIST) 98, version 2.0; Ringoes, NJ; Carbonell et al., 2002].

\section{Sensory Analysis}

A roundtable discussion with a 5-member panel was conducted to identify the descriptive flavor terms for the Sepet cheeses. The panelists were staff and graduate students in the Department of Food Engineering of Canakkale Onsekiz Mart University (Canakkale, Turkey). The panelists identified and defined the flavor terms from representative cheeses (Table 1). The panelists received about $50 \mathrm{~h}$ of training during identification and definition of descriptive terms. The panelists quantified the descriptive terms using 20-point product-specific scales anchored on the left with "not" and on the right with "very" (Meilgaard et al., 1999). The panelists were provided with water, unsalted bread, and expectoration cups. The cheeses were presented in plastic plates and coded with 3-digit numbers. Five samples were evaluated in each session. Panelists evaluated each cheese twice. Duplicate samples were served in different sessions (Karagul-Yuceer et al., 2007).

\section{Statistical Analysis}

Pearson correlation coefficients (r) were calculated to determine linear relations between the quality characteristics of Sepet cheeses. Analysis of variance and the Student-Newman-Keuls range test were performed to investigate the differences during production and ripening.

A nonmetric multidimensional scaling (MDS) method was also applied to provide a visual representation of distances among Sepet cheese samples collected from different towns located near Izmir, based on physicochemical, textural, sensory, and volatile characteristics. Multidimensional scaling is an ordination and numerical technique for finding a configuration of points in low-dimensional space that represents multivariate data. Multidimensional scaling plots the samples on a map where similar samples are placed near each other and different samples are located away from each other. The points close to each other on the map show the 
Table 1. Language used to evaluate Sepet cheese flavor

\begin{tabular}{|c|c|c|}
\hline Descriptor & Definition & Reference \\
\hline Whey & Aromatics associated with whey powder & Solubilize $5 \mathrm{~g}$ of whey powder in $100 \mathrm{~mL}$ of water ${ }^{1}$ \\
\hline Creamy & Aromatics associated with milk fat & Cream or butter ${ }^{1}$ \\
\hline Dirty moist cloth & Aroma associated with wet cloth & Dirty moist cloth \\
\hline Storage & Aromatics associated with warehouse & Long time stored cheese, assignment by panel \\
\hline Fruity & Aromatics associated with fruits & Fresh pineapple, ethyl hexanoate, $20 \mathrm{mg} / \mathrm{kg}^{2}$ \\
\hline Animal like & Aromatics associated with barns and stock & $5 \% \mathrm{Na}$-caseinate solution in water ${ }^{1}$ \\
\hline Sulfurous & Aromatics associated with sulfurous compounds & Boiled mashed egg ${ }^{1}$ \\
\hline Sour & Taste sensation elicited by acids & $0.08 \%$ citric acid solution in water ${ }^{3}$ \\
\hline Bitter & Taste sensation elicited by caffeine & $0.08 \%$ caffeine solution in water ${ }^{3}$ \\
\hline Salty & Taste sensation elicited by salts & $0.5 \%$ sodium chloride solution in water ${ }^{3}$ \\
\hline Sweet & Taste sensation elicited by sugars & $2 \%$ sucrose solution in water ${ }^{3}$ \\
\hline Umami & Chemical feeling factor elicited by certain peptides and nucleotides & $1 \%$ monosodium glutamate solution in water ${ }^{3}$ \\
\hline
\end{tabular}

${ }^{1}$ Reference adapted from Karagul-Yuceer et al. (2007).

${ }^{2}$ Reference adapted from Drake et al. (2001).

${ }^{3}$ Reference adapted from Meilgaard et al. (1999).

${ }^{4}$ Reference adapted from Friedeck et al. (2003).

relationship between the samples, as well as similarity of behavior with respect to the remaining samples. The points located on the plots reproduce distances between each sample and the distances among samples are calculated with an appropriate distance measure, such as Euclidean distance or Manhattan distance. This distance matrix is used for conducting MDS ordination. A stress coefficient and the proportion of variance of the scaled data are used to measure how well any given configuration fits the data. The smaller the stress, the better the representation (Kruskal, 1964; Başpinar et al., 2000; Karagul-Yuceer et al., 2007, 2009; Holland, 2008). Nonmetric MDS procedures deal with ordinal data, which implies less restrictive criteria of fit. Therefore, nonmetric MDS usually achieve solutions in the same or lower dimensionalities than metric factor analysis or principal component analysis (Rabinowitz, 1975). MacFie and Thomson (1984), Bieber and Smith (1986), Heymann (1994), Lawless et al. (1995), Popper and Heymann (1996) and Karagul-Yuceer et al. (2007, 2009) covered the use of MDS in sensory analysis of foods. Because different scales were used to measure characteristics of Sepet cheeses, data were standardized before the MDS method. A $52 \times 52$ symmetrical distance matrix was created with the dissimilarity measure (Euclidean distance) from the data, including 52 rows (each row represents each Sepet cheese sample) with columns, which include all physicochemical, textural, sensory, and volatile characteristics. The MDS ordination was performed on this matrix. All statisti- cal analysis was done using SPSS software (version 13; SPSS Institute Inc., Chicago, IL).

\section{RESULTS AND DISCUSSION}

\section{Physicochemical Parameters}

Dry matter, fat-in-DM, protein, salt-in-DM, water activity, $\mathrm{pH}$, and titratable acidity values of Sepet cheeses are given in Table 2. Except $\mathrm{NaCl}$ content, the remaining physicochemical parameters were similar to the results of previously reported studies about Sepet cheese by Kınık et al. (1999) and Karakaş and Korukluoğlu (2006).

Protein degradation is a part of the cheese aging process (Bynum and Barbano, 1985). Variations in ripening indices, and TCA-SN and TN ratios of Sepet cheeses were observed. Singh et al. (2003) reported that the final $\mathrm{pH}$, moisture, salt-in-moisture content, temperature, and time of ripening could be used to control proteolysis in cheese. Changes in those control parameters could be the reason for variation in levels of protein degradation in Sepet cheeses. Hayaloglu et al. (2008) explained that the reason for lower levels of $\mathrm{pH}$ 4.6-SN and TCA-SN in Kuflu cheese than of other mold-ripened cheeses may be because of the higher salt-in-moisture contents of Kuflu cheese samples. A significant negative correlation was observed between the level of TCA-SN and salt-in-moisture content $(\mathrm{r}=$ $-0.28, P<0.05)$. 
Table 2. Physicochemical characteristics of Sepet cheeses $(\mathrm{n}=52)$

\begin{tabular}{lrrrrr}
\hline $\begin{array}{l}\text { Physicochemical } \\
\text { characteristics }^{1}\end{array}$ & Mean & Minimum & Maximum & SD & CV \\
\hline DM (\%) & 55.16 & 44.56 & 64.39 & 5.13 & 9.30 \\
Fat-in-DM (\%) & 45.80 & 33.43 & 58.35 & 4.60 & 10.04 \\
Water in fat-free constituent (\%) & 59.87 & 48.45 & 74.92 & 6.02 & 10.05 \\
Protein (\%) & 29.18 & 24.40 & 33.69 & 2.25 & 7.72 \\
Salt-in-DM (\%) & 12.88 & 5.01 & 26.98 & 4.64 & 35.99 \\
Water activity & 0.83 & 0.74 & 0.91 & 0.05 & 5.88 \\
pH & 5.50 & 5.03 & 6.47 & 0.37 & 6.81 \\
Titratable acidity (\%) & 1.69 & 0.60 & 2.85 & 0.57 & 33.45 \\
Lipolysis index (acid degree value) & 6.36 & 1.64 & 41.63 & 7.23 & 113.77 \\
pH 4.6-SN/TN (\%; ripening index) & 11.06 & 3.33 & 34.52 & 7.40 & 66.91 \\
TCA-SN/TN (\%) & 8.56 & 1.89 & 28.02 & 6.18 & 72.22 \\
\hline
\end{tabular}

${ }^{1}$ Titratable acidity was expressed as $\mathrm{g}$ of lactic acid/100 $\mathrm{g}$ of cheese; SN/TN = soluble nitrogen/total nitrogen; $\mathrm{TCA}=$ trichloroacetic acid.

The lipolysis indices in Sepet cheeses varied considerably. The average lipolysis index was higher than the value reported by Kını et al. (1999). Lipolysis is related to lipases in cheese, originating from milk, rennet paste, starter, adjunct starter, or nonstarter bacteria, which could be different during production of cheese samples (Fox et al., 2000). The variation in lipolysis indices of Sepet cheeses could be related to variations in microbial loads, milk species, ripening conditions, and periods. Samples that had higher ripening and lipolysis indices than others were placed on the right-hand side of Figure 3.

\section{Textural Parameters}

Results of the TPA are given in Table 3. Variations were observed in textural parameters of Sepet cheeses. Figure 3 shows the similarities among the cheeses in terms of physicochemical, textural, sensory, and volatile characteristics, which were produced by MDS. Except cheeses $7,8,11,33,42,48$, and 50; all other cheeses grouped together close to the center of the graph (Figure 3). Most of the cheeses were similar in terms of physicochemical, textural, sensory, and volatile characteristics. Sample 42 and 43, due to their higher adhe-

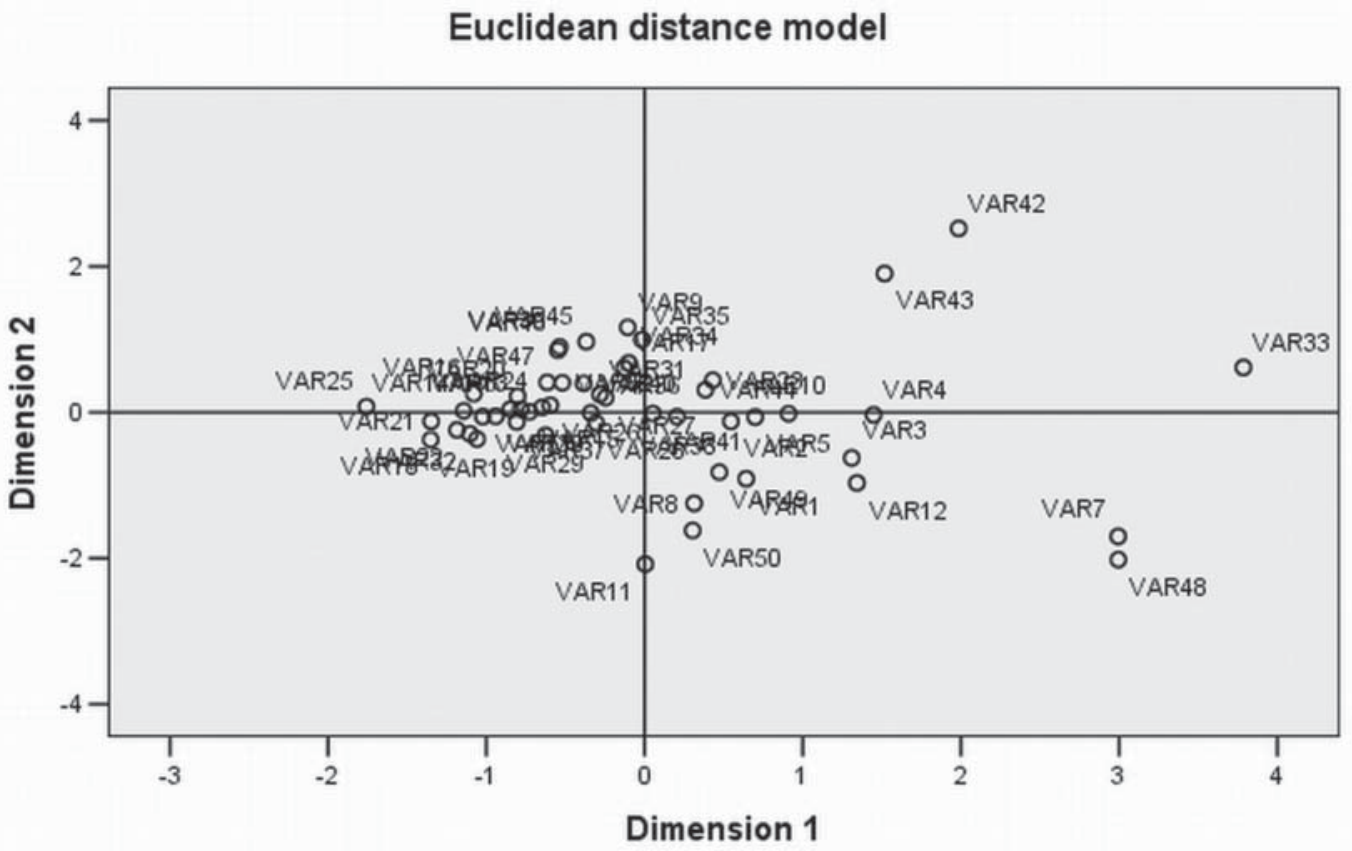

Figure 3. Geometrical representation of cheeses in terms of physicochemical, textural, sensory, and volatile characteristics by multidimensional scaling (MDS). Each Var represents a different cheese among 52 samples; stress coefficient $=0.19, \mathrm{R}^{2}=0.90$. 
siveness; samples 7, 8, 11, 48, and 50, due to their higher firmness and chewiness; and sample 33, due to its low springiness, were placed away from the other samples in Figure 3. Production technology, milk composition, moisture, $\mathrm{pH}$, salt content, lipolysis, and proteolysis occurring during ripening have effects on cheese texture (Lawrence et al., 1987; Fox et al., 2000; Gunasekaran and Ak, 2003). Firmness was significantly correlated with DM $(\mathrm{r}=0.66, P<0.01)$ and water-in-fat-free constituents content $(\mathrm{r}=-0.67, P<0.01)$. It was found that more than half of Sepet cheeses had 54 to $63 \%$ water-in-fat-free constituents content and these cheeses were considered as semi-hard cheese according to IDF (1981). Chewiness was also significantly correlated with $\mathrm{DM}(\mathrm{r}=0.48, P<0.01)$ and water-in-fat free constituent contents $(\mathrm{r}=-0.49, P<0.01)$. A significant negative correlation between fat in DM and firmness were observed ( $\mathrm{r}=-0.35, P<0.05)$. Similarly, Gwartney et al. (2002) and Gunasekaran and Ak (2003) stated that low-fat cheeses had a more compact protein matrix and harder texture than those of whole-fat cheeses. Firmness and salt contents were correlated significantly $(\mathrm{r}=$ $0.28, P<0.01)$. The correlation was in agreement with the results of the study of Prasad and Alvarez (1999). Fox et al. (2000) explained that salting affects cheese texture, due to protein solubility and protein conformation, and cause hard cheese texture. Significant negative correlation was observed between $\mathrm{a}_{\mathrm{w}}$ and firmness $(\mathrm{r}=$ $-0.49, P<0.01)$. Furthermore, significant correlations were observed between textural parameters and indices of ripening and lipolysis. Springiness and ripening index were negatively correlated $(\mathrm{r}=-0.45, P<0.01)$. Gunasekaran and $\mathrm{Ak}$ (2003) reported that the decrease in springiness occurred during ripening with the effects of proteolytic breakdown of the protein matrix. Firmness and the ripening index were negatively correlated $(\mathrm{r}=$ $-0.36, P<0.01$ ). Likewise, Brown et al. (2003) observed that firmness of cheeses decreased as the cheeses aged. Significant correlation between the lipolysis index and springiness was also observed $(\mathrm{r}=-0.44, P<0.01)$.

\section{Volatile Compounds Profile}

A total of 41 volatile compounds were identified in the headspace of Sepet cheeses (Table 4). Free fatty acids (FFA), ketones, aldehydes, esters, and others were found in the volatile fraction of Sepet cheeses. Sample 7, 33, and 48 were placed away from the other samples in Figure 3, because the odor intensities of esters and ketones were higher in those samples than of other Sepet cheeses. Sample 11 was also placed away from the rest in Figure 3 due to its high odor intensity of ethanol. Variations in flavor are mainly controlled by intricate biochemical reactions that occur due to the activities of starter cultures and their enzymes. These biochemical reactions are affected by the physicochemical properties of cheese and ripening conditions (Forde and Fitzgerald, 2000).

In all Sepet cheeses, FFA were the most abundant volatile compounds among all of the identified fractions. Hexanoic, octanoic, decanoic, and butyric acids had the highest percentages in the volatile fraction of Sepet cheese, in decreasing order. The GC/O results of FFA were also higher than of the other compounds. Hexanoic, octanoic, and butyric acids were perceived as a mild to strong goat-like, waxy, and cheesy odor. Ripening index was significantly correlated with odor intensities of butyric $(\mathrm{r}=0.30, P<0.05)$, hexanoic $(\mathrm{r}$ $=0.42, P<0.01)$, heptanoic $(\mathrm{r}=0.28, P<0.05)$, octanoic $(\mathrm{r}=0.46, P<0.01)$, and 4-methyloctanoic $(\mathrm{r}=$ $0.29, P<0.05)$ acids. Moreover, the lipolysis index was positively correlated with odor intensities of butyric $(\mathrm{r}$ $=0.47, P<0.01)$, hexanoic $(\mathrm{r}=0.58, P<0.01)$, octanoic $(\mathrm{r}=0.59, P<0.01)$, 4-methyloctanoic $(\mathrm{r}=0.44$, $P<0.01)$, and decanoic $(\mathrm{r}=0.33, P<0.05)$ acids. McSweeney and Sousa (2000) reported that linear FFA are generally produced from lipolysis of milk fat. The source of FFA can also be contributed by metabolism of deamination of AA and lipid oxidation (McSweeney and Sousa, 2000; Nogueira et al., 2005). Similarities were found between FFA of Sepet, Maltese goat milk, Minas, goat milk Jack cheese, and blue cheeses (Chiofalo et al., 2004; Frank et al., 2004; Nogueira et al., 2005; Attaie 2009). The esters in the volatile fraction of Sepet cheeses were ethyl hexanoate, ethyl decanoate, ethyl octanoate, and ethyl butyrate. The odor intensities of esters changed from medium to weak. These esters were appeared to be responsible for the characteristic fruity, green odor perceived in Sepet cheeses. Pinho et al. (2003) stated that most esters have effects on cheese

Table 3. Textural characteristics of Sepet cheeses $(n=52)$

\begin{tabular}{lccrrr}
\hline $\begin{array}{l}\text { Textural } \\
\text { characteristics }\end{array}$ & Mean & Minimum & Maximum & SD & CV \\
\hline Firmness (N) & 212.20 & 65.55 & 504.11 & 93.08 & 43.86 \\
Springiness (-) & 0.62 & 0.42 & 0.84 & 0.12 & 18.60 \\
Cohesiveness (-) & 0.57 & 0.21 & 1.56 & 0.23 & 40.59 \\
Adhesiveness (Nmm) & 0.48 & 0.00 & 14.34 & 2.43 & 511.59 \\
Chewiness (N) & 66.87 & 29.28 & 116.30 & 25.40 & 37.98 \\
\hline
\end{tabular}


Table 4. Volatile compounds of Sepet cheeses $(n=52)$

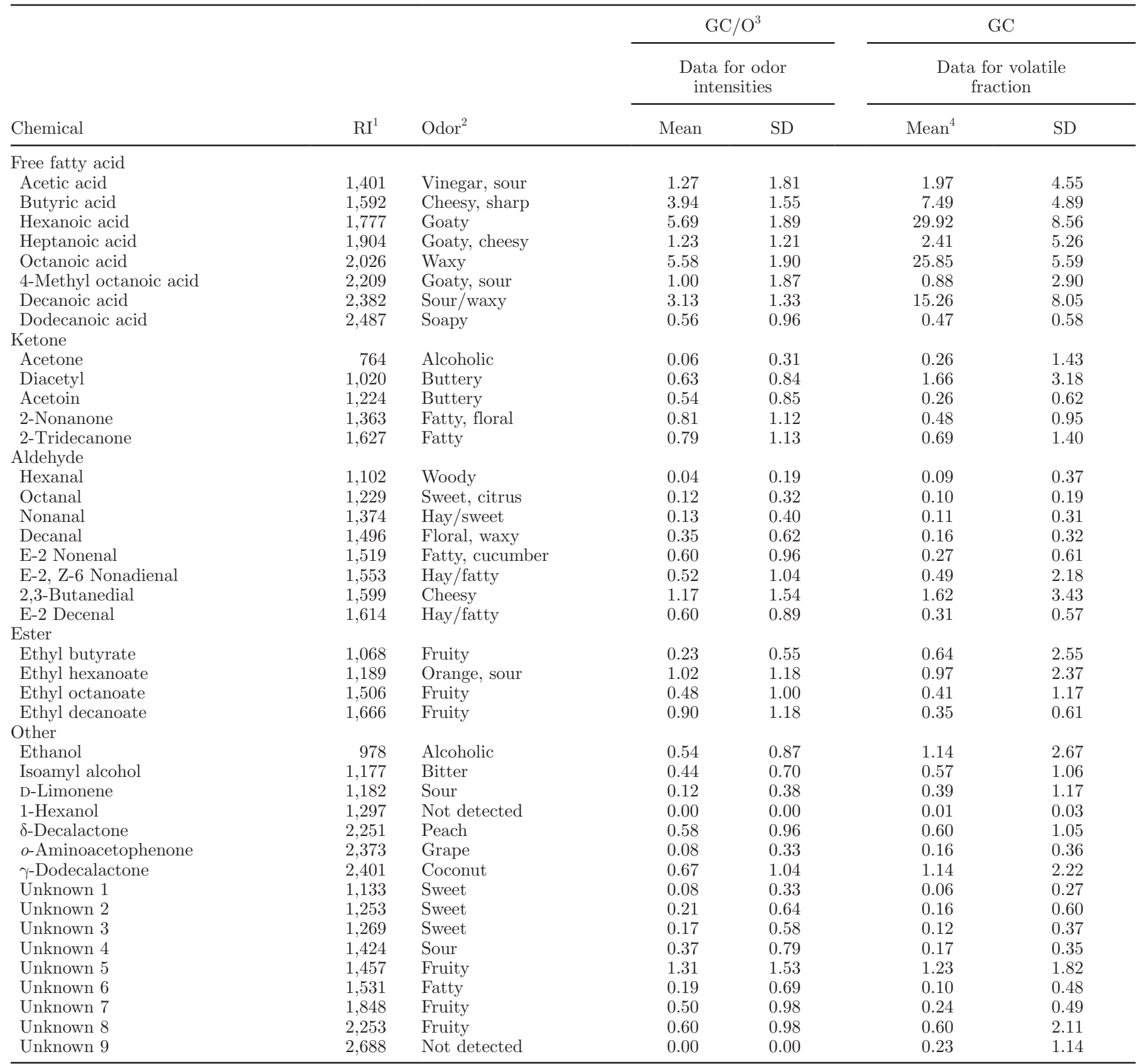

${ }^{1}$ Retention index on BP20 wax column.

${ }^{2}$ Odors were determined on olfactory port.

${ }^{3} \mathrm{GC} /$ olfactometry system.

${ }^{4}$ Mean values of $\%$ areas (area of component/total identified area).

aroma by minimizing the sharpness and the bitterness, which stem from the odors of fatty acids and amines, respectively. Significant positive correlations were observed between the lipolysis index and odor intensities of ethyl butyrate $(\mathrm{r}=0.30, P<0.05)$, ethyl octanoate $(\mathrm{r}=0.30, P<0.05)$, and ethyl decanoate $(\mathrm{r}=0.30, P$ $<0.05)$. Esters are produced by esterification of alco- hols and carboxylic acids, or alcoholysis of alcohols and acylglycerols or from alcohols and fatty acyl-coenzyme A (CoA) derived from the metabolism of fatty acids, AA, and carbohydrates (Liu et al., 2004). Similar esters were also observed in Parmigiano-Reggiano and Minas cheeses (Qian and Reineccius, 2002; Nogueira et al., 2005). Octanal, nonanal, decanal, (E,Z)-2,6-nonadienal, 


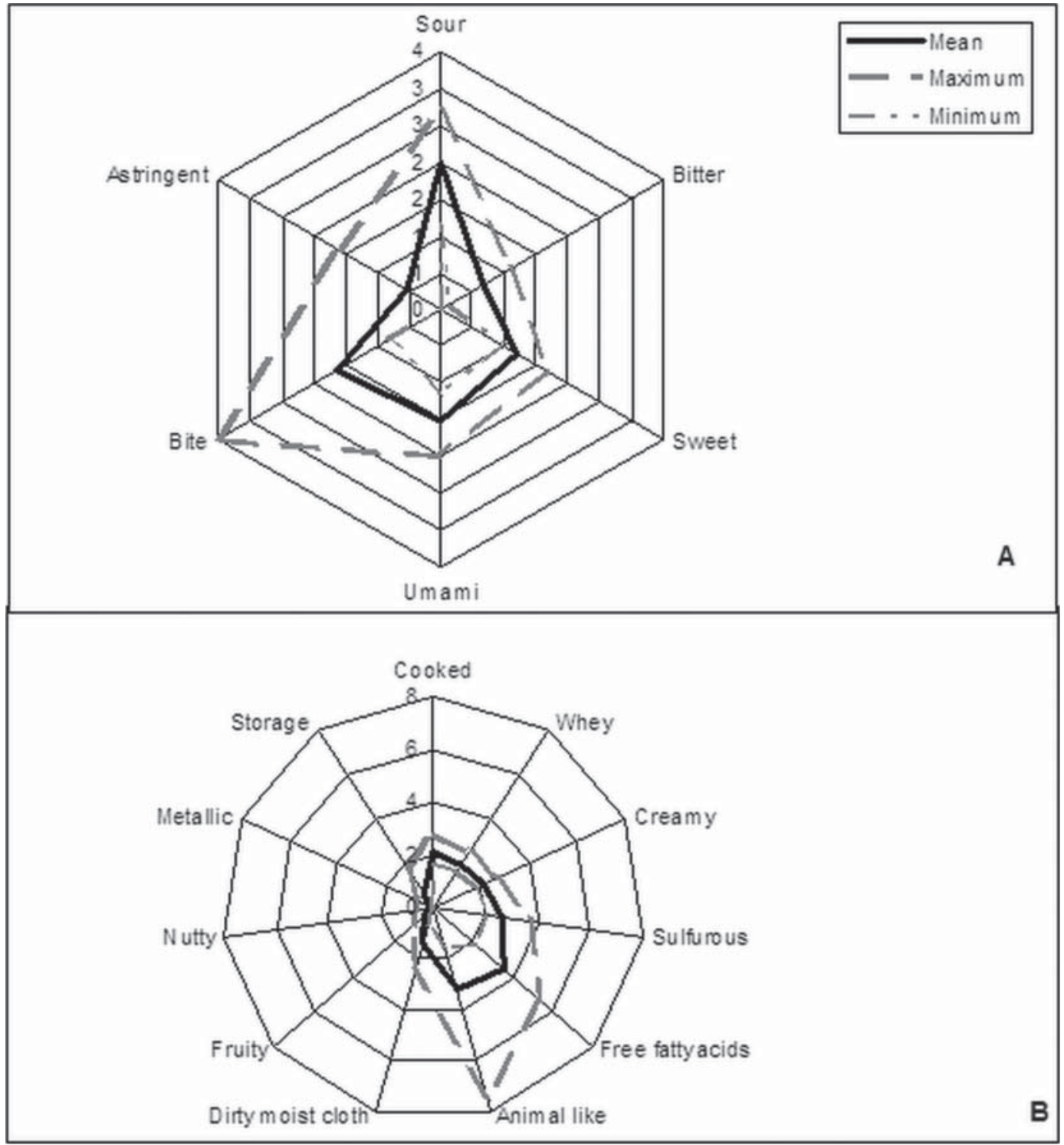

Figure 4. Flavor profile diagram of Sepet cheese $(\mathrm{A}=$ basic taste, $\mathrm{B}=$ aromatics $)$.

(E)-2-decenal, (E)-2-nonenal, and 2-3 butanedial were aldehydes found in Sepet cheeses. Although their fractions were low, they affected the aroma of Sepet cheeses with green and fatty odors. Carunchia Whetstine et al. (2003) reported that aldehydes affect the overall aroma of the goat cheese. Curioni and Bosset (2002) mentioned that aldehydes result from transamination or by Strecker degradation. The odor intensity of 2-3 butanedial was significantly correlated with the ripening index $(\mathrm{r}=0.28, P<0.05)$. Ketones such as acetoin, 2-nonanone, and 2-tridecanone were found in volatile fractions of Sepet cheeses. The formation of methyl ketones is a result of enzymatic oxidation of FFA to $\beta$-ketoacids and decarboxylation to alkan-2-ones with
1 less carbon atom (McSweeney and Sousa, 2000). The odor intensities of 2-tridecanone $(\mathrm{r}=0.42)$ and 2-nonanone $(\mathrm{r}=0.35)$ were significantly correlated with the lipolysis index $(P<0.01)$. The aroma intensity values of ketones changed between medium to weak among Sepet cheese samples. Frank et al. (2004) also found that 2-nonanone was important in blue cheese aroma. Similarly, Gonzalez De Llano et al. (1990) reported that the odd carbon-numbered ketones, especially 2-heptanone and 2-nonanone, were the most abundant compounds in the volatile fraction of artisanal Gamonedo blue cheeses. Similar ketones were also found in the volatile fraction of Tulum cheese by Hayaloglu et al. (2007). D-Limonene was detected in some Sepet cheeses 
and its odor intensities were recorded as weak. The occurrence of D-limonene is related to animal feeding and increases with green grass feeding (Chiofalo et al., 2004). Weak odor intensities of ethanol, isoamyl alcohol, $o$-aminoacetophenone, $\delta$-decalactone, $\gamma$-dodecalactone, and some unknown components were also observed in some Sepet cheeses.

\section{Sensory Profile}

Descriptive sensory analysis was performed to determine the basic tastes and aromatics of Sepet cheeses. The predominant basic taste was perceived as salty $(16.60 \pm 4.64)$ for all Sepet cheeses (not shown in Figure $4 \mathrm{~A}$ ). The other basic tastes that were perceived by panelists were sour $(2.00 \pm 0.49)$, bite $(1.64 \pm 0.73)$, umami $(1.52 \pm 0.26)$, sweet $(1.18 \pm 0.19)$, bitter $(0.66$ $\pm 0.28)$, and astringent $(0.52 \pm 0.61)$, in decreasing order (Figure 4A). Free fatty acid $(3.50 \pm 1.12)$, animal like $(3.22 \pm 1.26)$, sulfurous $(2.59 \pm 0.49)$, creamy (2.09 $\pm 0.27)$, cooked $(2.09 \pm 0.29)$, whey $(1.96 \pm 0.25)$, dirty moist cloth $(1.38 \pm 0.51)$, storage $(0.67 \pm 0.57)$, fruity $(0.52 \pm 0.22)$, nutty $(0.23 \pm 0.21)$, and metallic $(0.19 \pm 0.19)$ aromatics were observed as characteristic terms for Sepet cheeses, in decreasing order (Figure 4B). Some of these terms such as cooked, whey, fruity, sulfur, FFA, nutty, and FFA, creamy, and goaty were also used as descriptive terms for Cheddar and Ezine cheese, respectively (Drake et al., 2001; Karagul-Yuceer et al., 2007).

\section{Changes During Production and Ripening}

In the second part of the study, physicochemical parameters and volatile compounds were investigated during production and ripening. The changes in physicochemical parameters are given in Table 5. Milk used in dairy farms located in Germiyan town and Zeytineli town had $5.22 \pm 0.00 \%$ fat content, $0.57 \pm 0.00 \% \mathrm{TN}$, and $0.05 \pm 0.00 \%$ titratable acidity. The DM contents of cheeses produced in Germiyan and Zeytineli increased significantly during production due to the concentration of milk constituents in cheese $(P<0.01)$. The DM contents increased significantly up to the third month in Germiyan and sixth month in Zeytineli $(P<0.05)$. During ripening, an increase in salt content can cause a slight increase in DM content (Fox et al., 2000). During cheese production, titratable acidity significantly increased $(P<0.01)$. Tarakci and Kucukoner (2006) stated that the initial increase in acidity is due to lactic acid formation. During production of Sepet cheeses, $\mathrm{a}_{\mathrm{w}}$ decreased significantly $(P<0.01)$ due to the increase in DM content and the presence of salt. During production and up to the first month, salt-in-DM increased

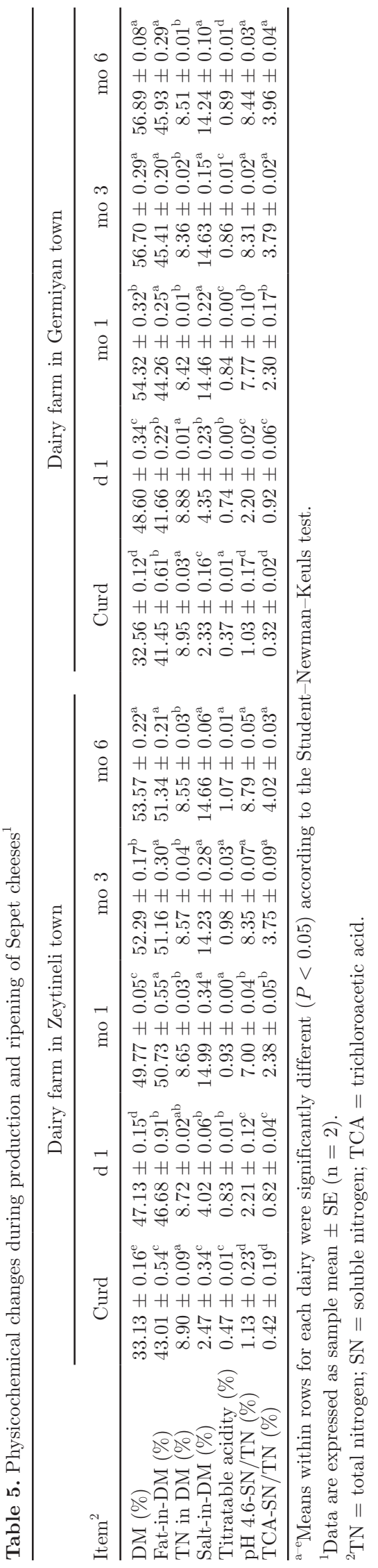


Table 6. Volatile compounds during production and ripening of Sepet cheeses ${ }^{1}$

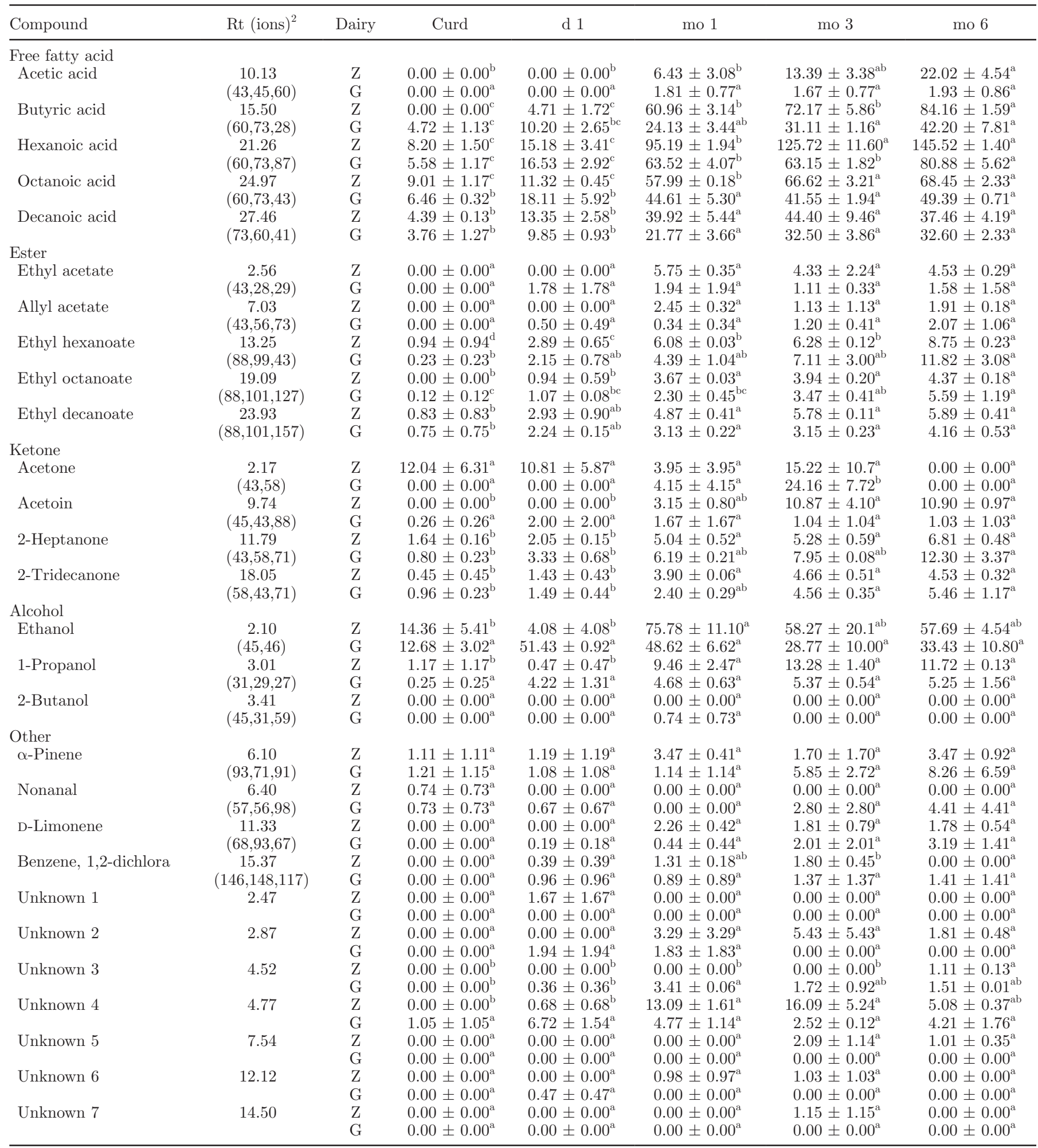

\footnotetext{
${ }^{\mathrm{a}-\mathrm{d}}$ Means within rows are significantly different $(P<0.05)$ according to the Student-Newman-Keuls test. ${ }^{1}$ Data are expressed as average peak area $\left(\times 10^{5}\right) \pm \mathrm{SE}(\mathrm{n}=2)$.

${ }^{2} \mathrm{Rt}=$ retention time; ions: used for detection; $\mathrm{Z}=$ dairy farm in Zeytineli town (Izmir, Turkey); $\mathrm{G}=$ dairy farm in Germiyan town (Izmir, Turkey).
} 


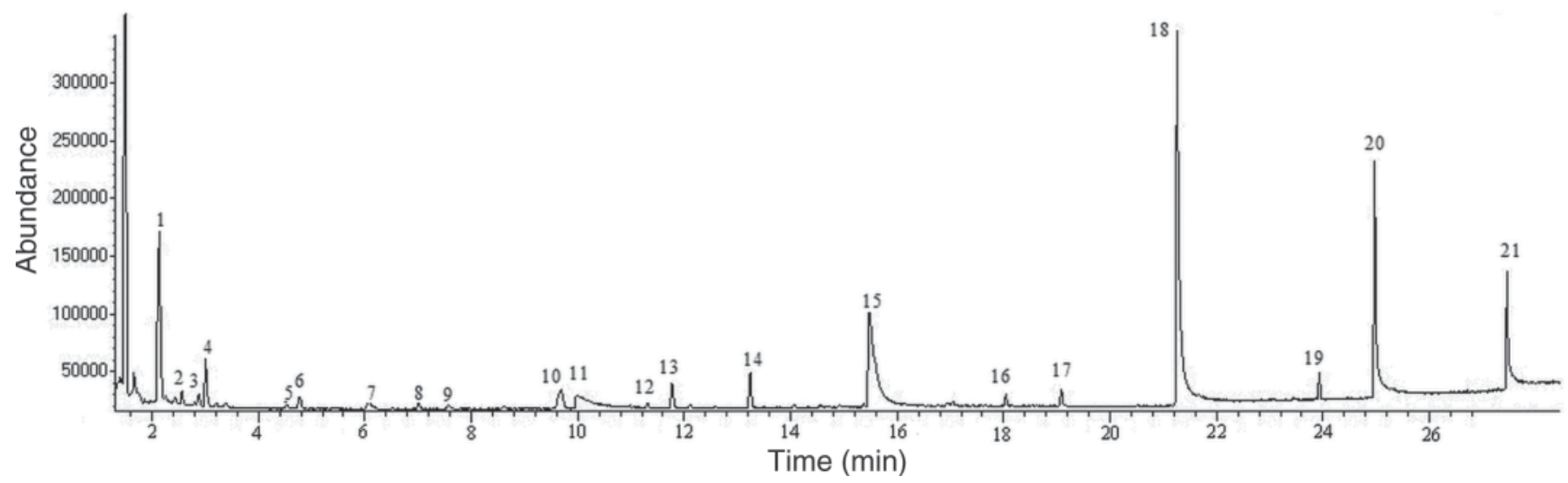

Figure 5. Gas chromatogram of volatile compounds of Sepet cheese produced in Zeytineli (Izmir, Turkey). ( $1=$ ethanol, $2=$ ethyl acetate, $3=$ unknown 2, $4=1$-propanol, $5=$ unknown $3,6=$ unknown $4,7=\alpha$-pinene, $8=$ allyl acetate, $9=$ unknown $5,10=$ acetoin, $11=$ acetic acid, $12=$ D-limonene, $13=2$-heptanone, $14=$ ethyl hexanoate, $15=$ butyric acid, $16=2$-tridecanone, $17=$ ethyl octanoate, $18=$ hexanoic acid, $19=$ ethyl decanoate, $20=$ octanoic acid, $21=$ decanoic acid).

significantly $(P<0.01)$. After the first month of ripening, no significant changes in salt, fat, and TN contents in DM of both cheeses were observed. The $\mathrm{pH}$ 4.6-SN and TCA-SN fractions increased during production and ripening up to the third month $(P<0.05)$. Then, a slight increase in fractions continued during ripening. No significant $(P>0.01)$ differences in fat-in-DM, $\mathrm{DM}$, salt-in-DM, TN in DM, pH 4.6 SN/TN, or TCA $\mathrm{SN} / \mathrm{TN}$ were observed among Zeytineli and Germiyan cheeses. Moatsou et al. (2004) investigated the effect of artisanal rennet on the characteristics of Feta cheeses and found that the use of artisanal rennet had no significant effect on the evolutions of TS, ash, $\mathrm{NaCl}$, fat, total protein, and proteolysis. A significant difference in titratable acidity was observed between Zeytineli and Germiyan cheeses. Zeytineli cheese produced with natural rennet had a higher lactic acid bacteria population than did Germiyan cheese that was produced with commercial rennet (data not shown). Olarte et al. (2000) reported the relation of lactic acid bacteria and initial lactic acid formation. Hatzikamari et al. (1999) also observed higher initial levels of lactic acid bacteria in low-pH cheeses.

Most of the volatile compounds identified were present at all stages of the Sepet cheese production and ripening. Indeed, their peak areas varied (Table 6). A sample chromatogram is given in Figure 5. All peak areas for FFA increased significantly up to the first month $(P<0.05)$. Then, slight increasing trends in decanoic and octanoic acids were observed in volatile composition of the cheese produced in Germiyan. The significant increases in hexanoic and butyric acids continued during ripening of cheese produced in Germiyan $(P<0.05)$. Significant increases in acetic, hexanoic, and octanoic acids were observed up to the sixth month in cheese produced in Zeytineli $(P<0.05)$. At the end of ripening, the peak areas of FFA in the volatile fraction of cheese that was produced in Zeytineli with natural rennet were greater than the peak areas of FFA in the volatile fraction of cheese that was produced with commercial rennet in Germiyan. The difference might have arisen from lipases in artisanal rennet that were not present in the commercial rennet. Horne et al. (2005) reported that artisanal cheese had greater frequency of hexanoic acid than the industrial cheese and a wild LAB strain from the raw milk or lipases in artisanal rennets might have caused this difference.

Most esters showed a significant increase until the first month. Alcohols such as ethanol and 1-propanol also significantly increased until the first month in volatile composition of the cheese produced in Zeytineli $(P$ $<0.05)$. Methyl ketones; 2-heptanone, and 2-tridecanone increased significantly $(P<0.05)$ until the first month of ripening and continued to increase slightly up to the third month. Same trends for FFA and esters were reported by Ziino et al. (2005) for Sicilian cheeses, by Tavaria et al. (2004) for Serra da Estrela Cheese, and by Pinho et al. (2001) for ewe cheeses.

\section{CONCLUSIONS}

In this research, the physicochemical, textural, volatile, and sensory profiles of traditional Sepet cheese, and changes in physicochemical and volatile composition during production and ripening were studied. Significant correlations were found between physicochemical and textural parameters and volatile compounds. It was concluded that the variability of odor intensities 
and textural parameters were mainly based on variations in some physicochemical parameters and ripening and lipolysis indices.

\section{ACKNOWLEDGMENTS}

This research was supported by the Research Funds of İzmir Institute of Technology (Project no 2008-İYTE17). The authors thank the Biotechnology and Bioengineering Research Center and Environmental Research Center of İzmir Institute of Technology (Turkey) for providing the $\mathrm{GC}$ and $\mathrm{GC} / \mathrm{MS}$ for aroma analysis. The authors also thank panel members for their participation.

\section{REFERENCES}

AOAC. 1995. Official Methods of Analysis. 16th ed. AOAC No. 920.124. Association of Official Analytical Chemists, Arlington, VA.

Attaie, R. 2009. Quantification of volatile compounds in goat milk Jack cheese using static headspace gas chromatography. J. Dairy Sci. $92: 2435-2443$.

Basspinar, E., M. Mendeș, and H. Camdeviren. 2000. Multidimensional scaling analysis and its usage. Biyoteknoloji (KUKEM) . Dergisi 24:89-98.

Beuvier, E., and S. Buchin. 2004. Raw milk cheeses. Pages 319-345 in Cheese: Chemistry, Physics and Microbiology. P. Fox, P. L. H. McSweeney, T. M. Cogan, and T. P. Guinee, ed. Elsevier Academic Press, London, UK.

Bieber, S. L., and D. V. Smith. 1986. Multivariate analysis of sensory data: A comparison of methods. Chem. Senses 11:19-47.

Brown, J. A., E. A. Foegeding, C. R. Daubert, M. A. Drake, and M. Gumpertz. 2003. Relationships among rheological and sensorial properties of young cheeses. J. Dairy Sci. 86:3054-3067.

Bynum, O. G., and M. D. Barbano. 1985. Whole milk reverse osmosis retentates for cheddar cheese manufacture: Chemical changes during aging. J. Dairy Sci. 68:1-10.

Carbonell, M., M. Nuñez, and E. Fernández-García. 2002. Evolution of the volatile components of ewe raw milk La Serena cheese during ripening. Correlation with flavour characteristics. Lait 82:683698.

Carunchia Whetstine, M. E. C., Y. Karagul-Yuceer, Y. K. Avsar, and M. A. Drake. 2003. Identification and quantification of character aroma components in fresh Chevre-style goat cheese. J. Food Sci. $68: 2441-2447$.

Chiofalo, A. Z., R. Costa, L. Liotta, L. Mondello, P. Dugo, and V. Chiofalo. 2004. Characterization of Maltese goat milk cheese flavor using SPME-GC/MS. S. Afr. J. Anim. Sci. 34:176-180.

Curioni, P. M. G., and J. O. Bosset. 2002. Key odorants in various cheese types as determined by gas chromatography-olfactometry. Int. Dairy J. 12:959-984.

Drake, M. A., S. C. McIngvale, P. D. Gerard, K. R. Cadwallader, and G. V. Civille. 2001. Development of a descriptive language for cheddar cheese. J. Food Sci. 66:1422-1427.

Everard, C. D., C. P. O'Donnell, D. J. O'Callaghan, E. M. Sheehan, C. M. Delahunty, B. T. O'Kennedy, and V. Howard. 2007. Prediction of sensory textural properties from rheological analysis for process cheeses varying in emulsifying salt, protein and moisture contents. J. Sci. Food Agric. 87:641-650.

Forde, A., and G. F. Fitzgerald. 2000. Biotechnological approaches to the understanding and improvement of mature cheese flavor. Curr. Opin. Biotechnol. 11:484-489.

Fox, P. F., T. P. Guinee, T. M. Cogan, and P. L. H. McSweeney. 2000. Fundamentals of Cheese Science. Aspen Publishers Inc. Frederick, MD.
Frank, D. C., C. M. Owen, and J. Patterson. 2004. Solid phase microextraction (SPME) combined with gas-chromatography and olfactometry-mass spectrometry for characterization of cheese aroma compounds. Lebensm. Wiss. Technol. 37:139-154.

Friedeck, K. G., Y. Karagül-Yüceer, and M. A. Drake. 2003. Soy protein fortification of a low-fat dairy-based ice cream. J. Food Sci. 68:2651-2657.

Gonzalez De Llano, D., M. Ramos, C. Polo, J. Sanz, and I. MartinezCastro. 1990. Evolution of the volatile components of an artisanal blue cheese during ripening. J. Dairy Sci. 73:1676-1683.

Gunasekaran, S., and M. M. Ak. 2003. Cheese Rheology and Texture. CRC Press LLC, Boca Raton, FL.

Gwartney, E. A., E. A. Foegeding, and D. K. Larick. 2002. The texture of commercial full-fat and reduced-fat cheese. J. Food Sci. $67: 812-816$.

Hatzikamari, M., E. Litopoulou-Tzanetaki, and N. Tzanetakis. 1999. Microbiological characteristics of Anevato: A traditional Greek cheese. J. Appl. Microbiol. 87:595-601.

Hayaloglu, A. A., E. Y. Brechany, K. C. Deegan, and P. L. H. McSweeney. 2008. Characterization of the chemistry, biochemistry and volatile profile of Kuflu cheese, a mould-ripened variety. LWT-Food Sci. Technol. 41:1323-1334.

Hayaloglu, A. A., S. Cakmakci, E. Y. Brechany, K. C. Deegan, and P. L. H. McSweeney. 2007. Microbiology, biochemistry, and volatile composition of Tulum cheese ripened in goat's skin or plastic bags. J. Dairy Sci. 90:1102-1121.

Heymann, H. 1994. A comparison of free-choice profiling and multidimensional scaling of vanilla samples. J. Sens. Stud. 9:445-453.

Holland, S. M. 2008. Non-metric multidimensional scaling (MDS) University of Georgia, Athens, GA. Accessed June 6, 2010. http:// www.uga.edu/strata/software/pdf/mdsTutorial.pdf.

Horne, J., S. Carpino, L. Tuminello, T. Rapisarda, L. Corallo, and G. Licitra. 2005. Differences in volatiles, and chemical, microbial and sensory characteristics between artisanal and industrial Piacentinu Ennese cheeses. Int. Dairy J. 15:605-617.

IDF (International Dairy Federation). 1981. Catalogue of cheeses. International Dairy Federation Bull. Doc. 141. International Dairy Federation, Brussels, Belgium.

IDF (International Dairy Federation). 1982. Cheese and processed cheese, determination of the total solids content. International Dairy Federation IDF Standard 4A. International Dairy Federation, Brussels, Belgium.

IDF (International Dairy Federation). 1988. Determination of salt content (Mohr method). International Dairy Federation IDF Standard 12B. International Dairy Federation, Brussels, Belgium.

IDF (International Dairy Federation). 1993. Milk-Determination of nitrogen content. International Dairy Federation IDF Standard 20B. International Dairy Federation, Brussels, Belgium.

IDF (International Dairy Federation). 1997. Milk and milk products: Determination of fat content (general guidance on the use of butyrometric methods). International Dairy Federation IDF Standard 152A. International Dairy Federation, Brussels, Belgium.

Kamber, U. 2008. The traditional cheeses of Turkey: The Aegean region. Food Rev. Int. 24:39-61.

Karagul-Yuceer, Y., M. Isleten, and C. U. Pala. 2007. Sensory characterization of Ezine cheese. J. Sens. Stud. 22:49-65.

Karagul Yuceer, Y., B. Tuncel, O. Guneser, B. Engin, M. Isleten, K. Yasar, and M. Mendes. 2009. Characterization of aroma-active compounds, sensory properties, and proteolysis in Ezine cheese. J. Dairy Sci. 92:4146-4157.

Karakas, R., and M. Korukluoğlu. 2006. A traditional cheese: Microbiological and chemical properties of Sepet cheese. Gida. 31:169172

Kınık, Ö., E. Ergüllü, and N. Akbulut. 1999. A study on the production and some characteristics of Sepet cheese. Gida. 24:151-161.

Kruskal, J. B. 1964. Multidimensional scaling by optimizing goodness of fit to a nonmetric hypothesis. Psychometrika 29:1-27.

Lawless, H. T., N. Sheng, and S. S. C. P. Knoops. 1995. Multidimensional scaling of sorting data applied to cheese perception. Food Qual. Prefer. 6:91-98. 
Lawrence, R. C., L. K. Creamer, and J. Gilles. 1987. Texture development during cheese ripening. J. Dairy Sci. 70:1748-1760.

Liu, S. Q., R. Holland, and V. L. Crow. 2004. Esters and their biosynthesis in fermented dairy products: A review. Int. Dairy J. 14:923-945.

MacFie, H. J. J., and D. M. H. Thomson. 1984. Multidimensional scaling. Pages 351-375 in Sensory Analysis of Foods. J. R. Piggott, ed. Elsevier Science \& Technology, London, UK.

McSweeney, P. L. H., and M. J. Sousa. 2000. Biochemical pathways for the production of flavor compounds in cheese during ripening: A review. Lait 80:293-324.

Meilgaard, M., G. V. Civille, and B. T. Carr. 1999. Sensory Evaluation Techniques. CRC Press, Boca Raton, FL.

Metin, M. 2006. Süt ve Mamülleri Analiz Yöntemleri. Ege Üniversitesi Ege Meslek Yüksek Okulları Yayınları No: 24. Izmir.

Moatsou, G., E. Moschopoulou, A. Georgala, E. Zoidou, I. Kandarakis, S. Kaminarides, and E. Anifantakis. 2004. Effect of artisanal liquid rennet from kids and lambs abomasa on the characteristics of Feta cheese. Food Chem. 88:517-525.

Nogueira, M. C. L., G. Lubachevsky, and S. A. Rankin. 2005. A study of the volatile composition of Minas cheese. LWT-Food Sci. Technol. 38:555-563.

Olarte, C., S. Sanz, E. Gonzalez-Fandos, and P. Torre. 2000. The effect of a commercial starter culture addition on the ripening of an artisanal goat's cheese (Cameros cheese). J. Appl. Microbiol. $88: 421-429$.

Picon, A., P. Gaya, E. Fernández-García, A. Rivas-Cañedo, M. Ávila, and M. Nuñez. 2010. Proteolysis, lipolysis, volatile compounds, texture, and flavor of Hispánico cheese made using frozen ewe milk curds pressed for different times. J. Dairy Sci. 93:2896-2905.

Pinho, O., I. M. P. L. V. O. Ferreira, S. Casal, J. O. Fernandes, M. B P. P. Oliveira, and M. A. Ferreira. 2001. Method optimization for analysis of the volatile fraction of ewe cheese by solid-phase microextraction. Chromatographia 53(Suppl.):S390-S393.

Pinho, O., C. Pérès, and I. M. P. L. V. O. Ferreira. 2003. Solid-phase microextraction of volatile compounds in "Terrincho" ewe cheese: Comparison of different fibers. J. Chromatogr. A 1011:1-9.

Popper, R., and H. Heymann. 1996. Analyzing differences among products and panelists by multidimensional scaling. Pages 1-35 in Multivariate Analysis of Data in Sensory Science. T. Naes and E. Risvik. ed. Elsevier, Amsterdam, the Netherlands.

Prasad, N., and V. B. Alvarez. 1999. Effect of salt and chymosin on the physico-chemical properties of feta cheese during ripening. J. Dairy Sci. 82:1061-1067.
Qian, M., C. Nelson, and S. Bloomer. 2002. Evaluation of fat-derived aroma compounds in blue cheese by dynamic headspace GC/Olfactometry-MS. J. Am. Oil Chem. Soc. 79:663-667.

Qian, M., and G. Reineccius. 2002. Identification of aroma compounds in Parmigiano-Reggiano cheese by gas chromatography/olfactometry. J. Dairy Sci. 85:1362-1369.

Rabinowitz, G. B. 1975. An introduction to nonmetric multidimensional scaling. Am. J. Pol. Sci. 19:343-390.

Renner, E. 1986. Milchpraktikum. Fachgebiet Milchwissenschaft. Justus-Liebig-Universität Giessen, Germany.

Sánchez-Macías, D., M. Fresno, I. Moreno-Indias, N. Castro, A. Morales-delaNuez, S. Álvarez, and A. Argüello. 2010. Physicochemical analysis of full-fat, reduced-fat and low-fat artisan-style goat cheese. J. Dairy Sci. 93:3950-3956.

Shakeel-Ur-Rehman, and F. P. Fox. 2002. Effect of added $\alpha$-ketoglutaric acid, pyruvic acid or pyridoxal phosphate on proteolyis and quality of Cheddar cheese. Food Chem. 76:21-26.

Singh, T. K., M. A. Drake, and K. R. Cadwallader. 2003. Flavor of Cheddar cheese: A chemical and sensory perspective. Compr. Rev. Food Sci. Food Safety. 2:139-161.

Tarakci, Z., and E. Kucukoner. 2006. Changes on physicochemical, lipolysis and proteolysis of vacuum packed Turkish Kashar cheese during ripening. J. Centr. Eur. Agric. 7:459-464.

Tarakci, Z., and H. Temiz. 2009. A review of the chemical, biochemical and antimicrobial aspects of Turkish Otlu (herby) cheese. Int. J. Dairy Technol. 62:354-360.

Tavaria, F. K., A. C. Silva Ferreira, and F. Xavier Malcata. 2004 Volatile free fatty acids as ripening indicators for Serra da Estrela cheese. J. Dairy Sci. 87:4064-4072.

Turkoglu, H., Z. G. Ceylan, and K. S. Dayisoylu. 2003. The microbiological and chemical quality of Orgu cheese produced in Turkey. Pakistan J. Nutr. 2:92-94.

Van den Dool, H., and P. D. Kratz. 1963. A generalization of the retention index system including linear temperature programmed gasliquid partition chromatography. J. Chromatogr. A 11:436-471.

Weichselbaum, E., B. Benelam, and H. S. Costa. 2009. Synthesis report No. 6: Traditional foods in Europe. European Food Information Resource (EuroFIR) Project Management Office, Institute of Food Research, Norwich, UK.

Ziino, M., C. Condurso, V. Romeo, D. Giuffrida, and A. Verzera 2005. Characterization of "Provola dei Nebrodi", a typical Sicilian cheese, by volatiles analysis using SPME-GC/MS. Int. Dairy J. 15:585-593. 